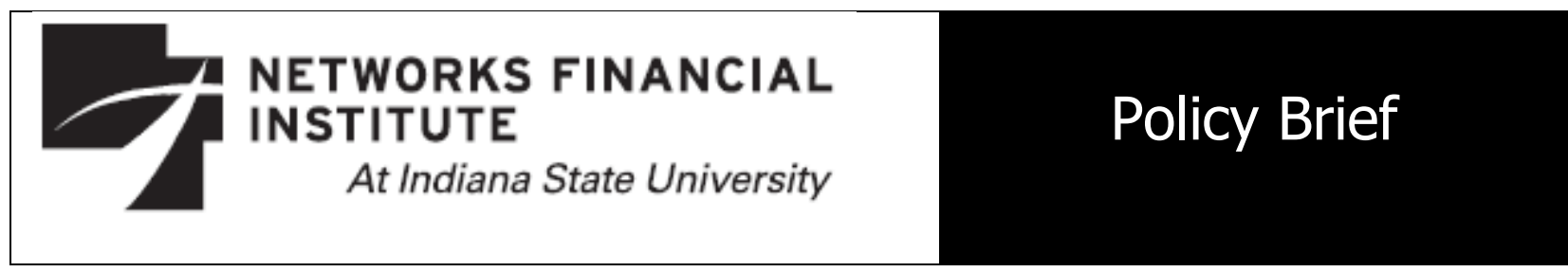

2009-PB-08C

November 2009; revised August 2010

\title{
The Importance of Monitoring and Mitigating the Safety-Net Consequences of Regulation-Induced Innovation \\ Edward J. Kane
}

Abstract: To be effective, programs of regulatory reform must address the incentive conflicts that intensify financial risk-taking and undermine government insolvency detection and crisis management. Subsidies to risk taking that large institutions extract from the financial safety net encourage managers to make their firms riskier, harder to supervise, and politically and administratively more difficult to fail and unwind. Except in the very short run, repealing the Gramm-Leach-Bliley Act or breaking up so-called too-big-to-fail institutions will do little to arrest subsidy-induced activities. Rebuilding Glass-Steagall barriers between banking, securities, and insurance firms would instead make implicit taxpayer support of large institutions less transparent and serve foreign interests by encouraging conglomerate firms to operate affected businesses through foreign subsidiaries. To discourage financial institutions from abusing safety-net support, government supervisors must be made specifically accountable for delivering and pricing safety-net benefits fairly and efficiently. If it wants to make the system more stable, Congress should focus on: rewriting top officials' oaths of office; changing the ways top officials are recruited, trained, and compensated; reworking the ways they measure and report regulatory performance; and changing the kinds of securities that large institutions have to issue.

About the Author: Edward J. Kane, Ph.D. is Professor of Finance at Boston College. He received his Ph.D. from Massachusetts Institute of Technology. Previously, Kane occupied the Everett D. Reese Chair of Banking and Monetary Economics at Ohio State University and also taught at Princeton University and Iowa State University. Kane has held several visiting professorships and is a past president and fellow of the American Finance Association and a former Guggenheim fellow. He serves on the editorial boards of several journals and is a founding member of the Shadow Financial Regulatory Committee. Currently, he consults for the World Bank and is a Senior Fellow in the FDIC's Center for Financial Research.

Keywords: Financial Crisis; Financial Reform; Gramm Leach Bliley Act; Glass-Steagall Act; Financial Safety Net; Accountability.

JEL Classification: G21, G28, G32, G38, F42.

For valuable comments on previous versions of this paper, the author wishes to thank Richard C. Aspinwall, Stephen Buser, Robert Dickler, Rex du Pont, Jack Reidhill, John Tatom, James Thomson, Larry Wall, Christopher Whalen, and the editor and referees of The Review of Social Economy. The views expressed are those of the individual author and do not necessarily reflect official positions of Networks Financial Institute. Please address questions regarding content to Edward Kane at kaneeb@bc.edu. Any errors or omissions are the responsibility of the author. NFI working papers and other publications are available on NFI's website (www.networksfinancialinstitute.org). Click "Thought Leadership" and then "Publications/Papers." 


\section{The Importance of Monitoring and Mitigating the Safety-Net Consequences of Regulation-Induced Innovation \\ Edward J. Kane}

As officials seek to identify the events and circumstances that generated the 2007-2009 financial crisis, they are attracted to explanations that deflect blame from themselves and the organizations they serve. The resulting array of seemingly authoritative explanations creates forward-looking policy turbulence. Conflicts between alternative crisis stories make it hard for outsiders to understand whether and how various proposed reforms might or might not reduce the frequency or depth of future crises. A particularly important issue concerns how giant U.S. financial institutions and automobile companies made themselves too difficult to fail and unwind (TDFU).

To a greater or lesser extent, official narratives are self-serving cover stories designed to heap credit on their authors and the institutions they lead, while shifting the blame for financial and macroeconomic turmoil into someone else's territory. With respect to any crisis, accountability for top government officials is a negative function of their "ability" to sell their own sterilized "account" of the time line of crisis and recovery.

The plausibility of the key elements in a cover story is sustained by a combination of mischaracterization, distortion, and distraction. A common tool is post hoc ergo propter hoc storytelling. The narrator starts by connecting the absence of crisis in the past to something or someone that departed the scene shortly before the crisis emerged. For example, one might note that the U.S. didn't experience a full-fledged financial crisis until after Alan Greenspan or Paul Volcker had left the Federal Reserve (Fed) and then claim that the absence of seasoned leadership explains both why the turmoil developed and why it degenerated into a disaster.

Obviously, this particular narrative would not serve the purposes of officials who held office during the crisis. By casting the nation's recent economic leaders as overmatched rookies, 
this story offers them no credit and considerable blame. Officials prefer stories that portray themselves as heroes who overcome odds as fearful as those faced by Horatius (and his brave colleagues Lartius and Herminius) at a bridge whose crossing would have allowed the most important country in the world (in their time, Rome) to be invaded by a deep depression. To avoid invidious comparisons with their predecessors, the story officials might choose could attribute the turmoil to weaknesses in the policy environment that previous officials (perhaps even Greenspan himself) might have mistakenly embraced.

The cover story that I perceive to be making the rounds among world leaders today traces the financial crisis to deregulation and to the Gramm-Leach-Bliley Act of 1999 (GLBA) in particular. The GLBA abandoned the regulatory strategy adopted after the Great Depression, which aimed at keeping banking, securities, and insurance firms from offering one another's traditional products. If this story were true and complete, repealing GLBA and simplifying the product lines of complex institutions would reduce the frequency and depth of future crises.

Almost every financial crisis is the product of overly aggressive leveraged risk taking. The GLBA did make it easier for institutions to expand and become more complex. But the GLBA did not arise in a vacuum and did not by itself make leverage or risk taking more attractive than it was before. To be complete, a theory of the crisis must explain why the GLBA was enacted, why so many loans were poorly underwritten, why counterparties failed to perform adequate due diligence along the chain of transactions traversed in securitizing and resecuritizing risky loans, and why borrowers and lenders chose to overleverage themselves.

In contrast, excessive risk taking, reduced due diligence, regulation-induced innovation, and the lobbying pressure that produced the GLBA can be explained by longstanding subsidies to risk taking that have been protected by the political and economic challenges of policing the 
safety-net consequences of regulation-induced innovation (Kane, 2009a). These challenges, and the limited liability that their stockholders and counterparties enjoy, make it easy for financial managers to extract ex ante and ex post implicit subsidies to leveraged risk taking from national safety nets (Kane, 2009b).

A complete story of the crisis must confront the economic and political difficulties of monitoring and controlling the production and distribution of safety-net subsidies. The next section of this paper discusses exclusionary regulations and the extent to which their relaxation enabled large financial institutions to make themselves harder to fail and unwind. This section seeks to explain that, although Gramm-Leach-Bliley contributed to the crisis, the re-introduction of a compartmentalization strategy would not prevent future crises. Section II of the paper explains that, to monitor and mitigate problems in controlling access to the federal safety net, government and private supervisory systems need doses of better information, better ethics, and better incentives. Meaningful reform requires that financial institutions be discouraged from abusing the benefits of safety-net support and that government supervisors be made specifically accountable for targeting and pricing safety-net benefits fairly and efficiently. Pursuit of safetynet subsidies can never be stopped, but it can be mitigated by changes in top officials' oath of office, changes in the ways officials are trained, recruited, and required to measure their performance, changes in financial-institution reporting responsibilities, changes in compensation structures, and changes in the kinds of securities TDFU institutions have to issue.

\section{Original Purposes and Declining Effectiveness of Exclusionary Laws}

The Glass-Steagall Act of 1933 and Bank Holding Company Act of 1950 are exclusionary laws intended to keep banks, securities, and insurance firms from poaching business from one another. Tailored to the less-complicated corporate structures that existed in 
the 1930s and 1950s, their stated purpose was to compartmentalize the activities of differently chartered firms so as to avoid potentially crippling concentrations of risk in individual financial firms and to constrain opportunities for multiproduct firms to take advantage of naïve customers.

Proponents of traditional compartmentalization policies had supposed that carefully restricting reciprocal entry into bank and nonbank financial activities could protect society from three kinds of potential harm (Benston, 1990, pp. 13-14; Saunders and Walter, 1994, pp. 134135). Microeconomically, proponents sought to lessen incentive conflicts, to assure a wide range of financial-services competitors, and to lessen opportunities for banks to engage in imprudent, improper, or abusive business practices. Particular attention focused on the possibility that banks might coercively tie sales of financial products that could be purchased from a nonbank (such as securities underwriting) to sales of a product (such as loans) in which banks enjoy a degree of monopoly power. Macroeconomically, proponents sought to limit opportunities for banks to expand their risk taking into activities that might destabilize their earnings sufficiently to disrupt financial markets by increasing the risk of widespread bank failures. Distributionally, proponents sought to protect taxpayers from the possibility of suddenly being handed a large bill for resolving bank insolvencies. The current crisis amply demonstrates that outsized costs can be shifted to taxpayers when institutional risk taking is effectively subsidized by mispricing and undersupervising loss exposures booked by institutions able to count on safety-net support.

Decades of mining advances in information, communications, and financial-contracting technologies for opportunities to restyle traditional products and organizational structures allowed institutions to destroy the effectiveness of compartmentalized charters by booking risks in innovative and nontransparent ways. The de jure barriers between the banking, securities, and insurance industries that the GLBA repealed in 1999 had become loophole-riddled remnants of 
their original selves. They provided no more protection for contemporary citizens than the scattered fragments of ancient city walls that tourists admire in ancient European cities today. Fresh blasts of circumventive innovation will destroy these barriers again if Congress decides to resurrect them. The principal effect of re-erecting federal restrictions to cross-industry competition in the U.S. would be to influence the country or state in which particular risk exposures would be booked. It would also distract Congress, regulatory personnel, and the news media from addressing the need to repair the defects in supervisory incentives that fostered the shortcutting and outsourcing of due diligence at every stage of the derivatives design and securitization process.

Because the Bank Holding Company Act still constrains industry turf, the GLBA may be characterized as lowering and regularizing the cost of circumventing this law. GLBA removed the need to spend resources on bypassing legal restraints on what banks may do and extends the range of differently chartered (i.e., "nonbanking”) financial corporations allowed to own a commercial bank.

The survival of compartmentalization strategies in the U.S. and the "desupervision" they engendered can be traced far more easily to the workings of money politics than to the conscientious pursuit of societywide benefits. Theories of lobbying pressure portray the GLBA's enactment as a threshold effect. Such theories presume that, as loopholes expanded and proliferated in piecemeal fashion, the political contributions that supported the compartmentalized regulatory regime dwindled and finally fell below the value that opponents were prepared to offer to eliminate most of what was left of the scheme. How Regulatory Competition Supports Regulation-Induced Innovation 
Regulation-induced innovation accepts rules, but attacks mechanisms for enforcing them. The loopholes that innovation opened in compartmentalization laws not only reduced their value to the sectoral interests that sponsored them, but also increased the number and complexity of definitional issues that supervisory authorities had to investigate and defend.

As distance-related communications and transportation costs moved closer and closer to zero, financial activity became more and more footloose. The ease of undertaking jurisdictionchanging innovations in financial contracting and organizational form rendered laws designed to compartmentalize the banking, securities and insurance industries increasingly irrelevant and difficult to enforce. In the years leading up to the enactment of the GLBA, U.S. courts became clogged with cases requiring judges to rule on whether or not an innovative contract, corporate structure, or cross-institutional delivery system had successfully moved a bank, securities firm, derivatives contract, or insurance company beyond the prescribed reach of a particular law or regulator (see, for example, Anderson, 1993; Sivon, 1992; Turner, 1993).

Banking practices and market environments differ markedly over time and space. Much of this variation is driven by an irreconcilable tension between adjustments in regulation or supervision (on the one hand) and loophole-seeking avoidance activity undertaken to make regulatory interference less burdensome (on the other hand). Regulation begets avoidance activity, and avoidance eventually begets some form of reregulation. Regulatory problems, adjustments, and market events unfold and mutate as part of alternating sequences in which either regulation spawns new forms of avoidance (RA sequences) or the growing effectiveness of particular avoidance activities finally results in a threshold level of avoidance activity ( $\left.\mathrm{A}^{*}\right)$ that calls forth innovative reregulation ( $\mathrm{A} * \mathrm{R}$ sequences). Adapting regulatory protocols to innovative avoidance activity is an endless task. Each and every piece of regulatory re-engineering kicks off 
a series of RAA*R sequences. Inevitably, the range, size, and speed of regulation-induced innovation outpaces the vision and disciplinary powers that regulatory authorities can bring to bear. The current crisis tells us that, in recent years, across the chain of adjustments by regulators and regulated institutions, risk-taking incentives became more and more dangerously misaligned with societal interests. But this process began and gained momentum long before GLBA was enacted.

As national markets became highly connected and traditional products developed more and more potential substitutes, compartmentalization strategies were bound to become riddled with loopholes. Regulators and legislatures in different jurisdictions compete eagerly with one another for regulatory domain and seem all too willing to accept as tribute a mere fraction of the incremental value that the loopholes they create generate for the hard-lobbying firms that rely on them.

In the face of continuing foreign (especially European Union) regulatory competition, the ease of locating viable loopholes and the resource costs of adjudicating the permissibility of creative product-line and organizational transformations make it foolish to try to roll back the clock. A strategy of formally walling off the parts of a complex financial firm that formally enjoy safety-net support is unenforceable today. Realistically, the societal benefits compartmentalization could achieve in the 1930s have for years had to be pursued in other ways. Most other developed countries acted far earlier than the U.S. to allow domestic and foreign banks to sell insurance and securities products and permitted either direct or indirect crossindustry ownership of bank, securities, and insurance organizations (Borio and Filosa, 1994; Hough, 1991; Posner, 2009). Rebuilding cross-industry barriers in the U.S. will make safety-net exposures less transparent and serve foreign interest by intensifying incentives for TDFU firms 
to undertake activities in competing countries through foreign subsidiaries. This means that to improve the operation of the U.S. safety net, one must also worry about improving the ways that the U.S. net links up with nets operated by other countries.

Large U.S. financial firms operate in a regime of multiple regulators. The absence of cross-country agreements for sharing resolution costs in the event of a multinational firm's insolvency encourages incentive-conflicted regulatory competition. Ambiguity about which country's taxpayers can be saddled with the bill for safety-net losses reduces accountability for supervisory and regulatory mistakes. It incentivizes politicians and regulators in different countries to compete aggressively for footloose financial-institution capital and employment. It also encourages officials to blame not themselves but foreign regulators if and when the risky business they have competed for falls into distress.

\section{Strategies To Reduce Safety-Net Subsidies To TDFU Institutions ${ }^{1}$}

In a context where it pays multinational financial conglomerates and national champion banks to make themselves harder and harder to supervise, policymakers' root problem is not how to make TDFU firms smaller or less complicated. Nor is it how to make financial firms more transparent and administratively easier to fail and unwind (although that would be helpful). The root problem is how to design and manage national safety nets so that they do not deliver subsidies to firms when they expand their political clout, organizational complexity, and/or risk taking in clever ways.

Plans to establish a systemic-risk regulator for U.S. firms will go awry unless proponents find a way to track and control the migration of insolvency risk to other jurisdictions. To be effective, programs of regulatory reform must address the sources of the agency costs that intensified problems in industry risk taking and in government insolvency detection and crisis

\footnotetext{
${ }^{1}$ This section makes use of ideas and material from Kane (2009a and c).
} 
management. To confront these issues squarely, Congress and the Obama Administration must focus beyond mere adjustments in form and bureaucratic structure to improve - within the U.S. and across countries - the information firms and authorities produce, the types of securities TDFU firms have to issue, and the incentives under which private financial managers and government safety-net officials operate.

\section{Improving Incentives in the Private Sector}

To help safety-net managers to serve taxpayers better, large institutions must be tasked with making safety-net loss exposures in their firms easier to detect and cheaper to resolve. Detection can be improved by developing explicit metrics for measuring the value of safety-net support at individual institutions and requiring safety-net beneficiaries to use these metrics to estimate the value of their safety-net support and report this value at regular intervals at least to their principal supervisor. Ideally the task of aggregating these estimates across firms and agencies should be assigned to a new federal entity specifically charged with measuring and monitoring safety-net costs and benefits (Lo, 2009).

Although still provisional, researchers have developed a number of metrics for assessing the value of safety-net support. Carbo, Kane, and Rodriguez (2009) estimate the value of safetynet support from data on a banking organization's stock price. Baker and McArthur (2009) extract estimates from a firm's credit spread. Hart and Zingales (2009) focus on the price of credit default swaps. Huang, Zhou, and Zhu (2009) use stock price, credit spreads, and credit default swap data simultaneously. If the analytical resources of the world's central banks and largest institutions can be incentivized to attack this estimation problem on a massive scale, the confidence intervals that practitioners have to build around different point estimates should decline rapidly in the future. 
It would also be helpful to require financial firms to plan explicitly for the downside. To my knowledge, Richard Herring and Jacopo Carmassi (2009) were the first to propose that managers be required to prepare and file with their principal regulator a standby plan with which to handle their firm's bankruptcy and be obliged to test, update, and refile this plan on a regular basis. The existence of an up-to-date corporate "living will" would make the threat of putting an insolvent institution into receivership or conservatorship more credible because it would lower the costs of executing the threat. Unlike the chaotic haggling observed in addressing the insolvencies of Lehman Brothers and American International Group (AIG) in September 2008, having a benchmark winding-up scheme in place would make it much easier for authorities to wipe out the claims of stockholders and to negotiate prearranged haircuts for uninsured creditors as the threat of bankruptcy increased.

\section{Types of Securities Issued}

Explicitly planning for liquidation or breakup is one way of making insolvencies cheaper to handle. Another way is to re-establish extended liability for at least some owners of financialinstitution stock. A mitigatable source of incentive conflict in industry risk taking and loss generation is the limited liability that stockholders enjoy. The less capital they have invested in the firm, the more valuable safety-net support becomes to them and their counterparties. Extended stockholder liability makes holders of assessable shares in a liquidating firm responsible for covering a layer of corporate losses beyond the value of the capital previously accumulated at the corporate level. Several now-industrialized countries (including the United Kingdom, the U.S. and Canada) imposed extended liability on bank shares when their safety nets and private contacting environments were less well developed. 
Extended liability increases transparency, counterparty disciplinary rights, and regulatory accountability at the same time. It increases transparency by transforming movements in the stock price of publicly traded banks into a clearer signal of institutional strength or weakness. Extended liability means that a supervisor's right to liquidate an insolvent commercial or investment bank carries with it a right to collect specified amounts of additional funds from the personal or corporate assets of assessable stockholders. As compared to limited-liability shareholding, deterrence is enhanced by stockholders' duty to pony up additional funds if (but only if) managers and regulators allow the institution to become so insolvent that it passes into liquidation.

To create an opportunity to claw back compensation that personnel might earn from exploiting the safety net, bonuses and incentive compensation could be paid in slow-to-vest assessable stock. Stock markets would imbed the value of this contingency into the price of each TDFU firm's assessable shares and traders could fashion derivative instruments that capture various tranches of the loss exposure it entails. Like safety-net subsidies, the value of the contingency would be negligible for institutions that were performing well and adequately supporting their risk with paid-in corporate capital. However, the resolution authority's claim on off-balance-sheet stockholder resources would become increasingly valuable whenever a TDFU firm began to take poorly supported risks or to slide into financial distress. By increasing the sensitivity of TDFU stock prices to changes in earning power and earnings volatility, assessable shares would encourage information-revealing stockholder doubt about the viability of troubled institutions in advance of their final slide into complete economic insolvency. Because doubts would emerge gradually, "runs" on an institution's assessable stock would be far less 
catastrophic than the sudden meltdowns that inattentive regulators allowed Bear Stearns, Fannie Mae, Freddie Mac, AIG, and Lehman Brothers to experience in 2008.

A sustained sell-off by worried stockholders would increase the quality of counterparty and regulatory supervision by helping safety-net managers to identify institutions that deserve increased supervisory attention long before the enterprise-contributed capital of these institutions could become exhausted. The idea is to create a pool of contingent private capital that would be drawn inescapably onto an institution's balance sheet when and as it first falls into distress. Mark Flannery's proposal for contingent capital certificates (2009) would do this very well if an appropriate market-based trigger for forcing the debt-to-equity conversions can be found. Sharp declines in the price of a financial institution's stock could reinforce regulator-initiated triggers if large financial firms were required to issue extended-liability stock.

\section{Improving Incentives in Government}

Incentive conflict in government is rooted in three circumstances. First, no one is charged with measuring and monitoring safety-net subsides per se. Second, top government officials have horizons much shorter than the taxpayers they formally serve. Third, taxpayers are not their only principals. Different principals differ in at least four important ways: in their understanding of the duties officials owe them; in their ability to influence policy decisions as they are being made; in their ability to appreciate the consequences of alternative policy decisions; and in their ability to offer rewards for bending policy in the directions they prefer. The result is that officials feel disproportionately accountable to residents of sectors that make themselves particularly well-informed and politically powerful.

Requiring private institutions to prepare a regulator-certified unwinding plan and to estimate the value of their safety-net support would sharpen the missions of micro- and macro- 
prudential regulators. Besides verifying estimates of the value of safety-net support supplied by institutions under their purview, regulators could be further tasked with establishing, publicizing, and testing periodically a benchmark market-mimicking scheme for insolvency management.

While authorities would be free to deviate from their benchmark plan in an actual crisis, they would be obliged to explain why they are doing so. To help them to put crisis-management plans into operation more promptly, I would also require them to aggregate the estimates of safety-net subsidies that individual institutions produce. Each micro-prudential regulator would consolidate these estimates in ways that would track over time the aggregate value of safety-net benefits for firms they supervise. I would ask the Treasury, the Fed, the Office of the Comptroller, the Securities and Exchange Commission, the Commodities Futures Trading Commission, the Federal Deposit Insurance Corporation, credit union regulators, and the Office of Thrift Supervision (if it survives) to use these estimates and other relevant data to construct independent estimates of the evolving value of safety-net subsidies to the financial sector as a whole.

To discourage elected officials from trying to win special treatment for firms that contribute money to their campaigns, it would be useful to require that regulatory personnel report promptly and fully on interactions with elected officials that occur outside the public eye.

Obviously, these reforms would make the jobs and recruitment of top regulators more difficult. For this reason, Congress would be well advised to establish the equivalent of a West Point for financial regulators and admit students from around the world. Coupled with appropriate changes in regulators' oaths of office, such an academy would raise the prestige of this career path and instill a stronger and broader sense of communal duty in safety-net managers. In view of the damage crises can cause, it is hard to understand why regulators are not 
trained and incentivized as thoroughly as military, police, firefighting, and nuclear safety personnel.

It would also be appropriate to raise the salaries of top officials. However, to lengthen the horizons of safety-net managers, the raise should be framed as deferred compensation that would have to be forfeited if a crisis occurred within three or five years of their leaving office. While the incremental loss of income might seem trivial, the impact on a regulator's backbone could be considerable. If payouts were tied to measures of safety-net subsidies, deferred compensation would have the further benefit of making new appointees more cognizant of unresolved problems that his or her predecessor might be leaving behind.

In principle, supervisors should be willing to embrace the duties they owe society explicitly and be prepared to perform them selflessly and conscientiously. Ideally, oaths of office could be reworked to include five duties that conscientious supervisors ought to agree that they owe to the community that employs them:

1. A duty of vision: Supervisors should continually adapt their surveillance systems to discover and neutralize innovative regulatee efforts to disguise their rule breaking;

2. A duty of prompt corrective action:_Supervisors should stand ready to propose new rules and to discipline regulatees whenever a problem is observed;

3. A duty of efficient operation: Supervisors should strive to produce their insurance, loss-detection, and loss-resolution services at minimum cost; and

4. A duty of conscientious representation: Supervisors should be prepared to put the interest of the community they serve ahead of their own.

5. A duty of accountability: Implicit in the other four duties is an obligation to make themselves politically accountable by bonding themselves to disclose enough 
information about their decision making to render themselves answerable for mishandling their responsibilities.

Legislatures could further sharpen monitoring and loss-control responsibilities by establishing schemes in which private and governmental monitors could hold one another financially responsible for the quality of their work. For example, Congress has proposed imposing product liability on credit-rating organizations and requiring safety-net managers to move trading in over-the-counter derivatives and other securities to clearinghouses or exchanges when and as their volume becomes large enough to pose material safety-net consequences. This duty would be strengthened if deposit insurers were made to reinsure with private parties the coverage they provide to over-the-counter market makers in derivative instruments. This could be done either by writing credit default swaps or by transacting directly in reinsurance markets.

\section{Summary Implications}

It is important to recognize that the current financial crisis is rooted in the economic and especially the political - difficulties of monitoring and controlling the production and distribution of safety-net subsidies. Regulation-induced innovation by financial firms seeks relentlessly to outstrip the monitoring technology and the administrative focus that supervisory personnel use in controlling institutional risk taking. Exclusionary laws and rigid capital regulation encourage rather than control regulatory arbitrage over time.

Safety-net subsidies are easy to overlook in good times. To reduce the threat of future crises, the pressing task is not to rework bureaucratic patterns of financial regulation, but to repair defects in the information flow and incentive structure under which private and government supervisors manage the safety net. The mission of these managers is to balance the costs and benefits generated by: (1) protecting financial-institution customers from being 
blindsided by insolvencies; (2) limiting aggressive risk taking by financial firms; (3) preventing and controlling damage from runs; (4) detecting and resolving insolvent institutions; and (5) allocating across society whatever losses occur when an insolvent institution is closed (Kane, 2001).

Proposals to reinstitute formal limits on the scope of a country's financial safety net can easily degenerate into cheap talk. In the U.S. and other countries, such limits have repeatedly melted away under the pressure of an actual crisis. Unless new rounds of limits on the safety net are backed up by incentive reform and solid crisis planning, they will create a false sense of security that is apt to foster new and more devastating crises and the continued extension of national nets. Crisis planning is important because the more effective a nation's safety net becomes, the less likely it is that regulatory personnel will have prior hands-on experience in coping with the severity of crisis pressures.

By themselves, redesigning regulatory instruments and relocating bureaucratic responsibilities for different features of the safety net will not do much to slow processes of regulatory arbitrage. Such steps can be made much more meaningful if they are accompanied by actions that make financial-institution managers and federal regulators accountable for estimating and controlling in a timely manner the safety-net consequences of transformative financial contracts and institutional structures. 


\section{REFERENCES}

Anderson, William R., 1993. "The Struggle Between Federal Banking and State Insurance Laws," Life Association News, 88 (December), 124-127.

Baker, Dean, and Travis McArthur, 2009. "The Value of the "Too Big to Fail" Big Bank Subsidy." Washington, DC: Center for Economic and Policy Research Issue Brief (September).

Benston, George J., 1990. The Separation of Commercial and Investment Banking: The GlassSteagall Act Revisited and Reconsidered. NY: Oxford University Press.

Borio, Claudio, and Renato Filosa, 1994. The Changing Borders of Banking. Basle: Bank for International Settlements Monetary and Economic Department (October).

Carbo-Valverde, Santiago, Edward Kane, and Francisco Rodriguez-Fernandez, 2009. "Evidence of Regulatory Arbitrage in Cross-Border Mergers of Banks in the EU." National Bureau of Economic Research Working Paper No. 15447.

Carmassi, Jacopo, and Richard Herring, 2009. "The Corporate Structure of International Financial Conglomerates: Complexity and Its Implications for Safety and Soundness," Oxford Handbook of Banking. Allen N. Berger, Phillip Molyneux and John O. S. Wilson, eds. NY: Oxford University Press.

Flannery, Mark J., 2009. "Stabilizing Large Financial Institutions with Contingent Capital Certificates." Unpublished University of Florida Working Paper (September 18).

Hart, Oliver, and Luigi Zingales, 2009. "A New Capital Regulation for Large Financial Institutions," Chicago Booth Research Paper No. 09-36 (October 2).

Hough, Vince, 1991. "Banks and Insurance: The Lesson from Abroad," Best's Review (March), 25-26, 28, 30.

Huang, Xin, Hao Zhou, and Haibin Zhu, 2009. "A Framework for Assessing the Systemic Risk of Major Financial Institutions.” Working Paper, University of Oklahoma (May).

Kane, Edward J., 2001. "Financial Safety Nets: Reconstructing and Modeling a Policymaking Metaphor." Journal of International Trade and Development, 3, 237-273.

., 2009a. "Incentive Roots of the Securitization Crisis and Its Early Mismanagement," Yale Journal on Regulation, 26 (Summer), 405-416.

, 2009b. "Extracting Nontransparent Safety Net Subsidies by Strategically Expanding and Contracting a Financial Institution's Accounting Balance Sheet," Journal of Financial Services Research, 35 (December). 
, 2009c. "Discussion of 'An Industrial Organization Approach to the Too Big to Fail Problem' by Jean-Charles Rochet.” Prepared for Federal Reserve Bank of Boston 54th Economic Conference in Chatham, MA (October).

Lo, Andrew W., 2009. "The Feasibility of Systemic Risk Measurement," Testimony Before the Financial Services Committee of the U.S. House of Representatives (October 19).

Posner, Elliot, 2009. The Origins of Europe's New Stock Markets. Cambridge: Harvard University Press.

Saunders, Anthony, and Ingo Walter, 1994. Universal Banking in the United States, NY: Oxford University Press.

Sivon, James C., 1992. "Insurance Activities Permissible for Banks and Bank Holding Companies," Washington, DC: American Bankers Association (April).

Turner, Bob, 1993. "Bank Sale of Life Insurance: The Ideal Solution,” Banks in Insurance Report, 11-13. 


\section{APPENDIX TABLES ON FINANCIAL SECTOR LOBBYING COMPILED BY CONSUMERWATCHDOG.ORG}

TABLE 1.

CONTRIBUTIONS: Senate Banking Committee Financial Sector Contributions, 2005-2009

\begin{tabular}{|c|c|c|c|}
\hline Senator & $\begin{array}{l}\text { Raised from } \\
\text { Financial } \\
\text { Industry }\end{array}$ & $\begin{array}{c}\% \text { of Total } \\
\text { Funds Raised }\end{array}$ & $\begin{array}{c}\text { Fundraising Events } \\
\text { Hosted by Financial } \\
\text { Sector* }\end{array}$ \\
\hline Christopher J. Dodd (D-CT) & $\$ 9,000,975$ & $51 \%$ & 1 \\
\hline Mark Warner (D-VA) & $\$ 5,561,561$ & $40 \%$ & - \\
\hline Charles E. Schumer (D-NY) & $\$ 4,086,349$ & $31 \%$ & 4 \\
\hline Evan Bayh (D-IN) & $\$ 3,020,913$ & $23 \%$ & 2 \\
\hline Bob Corker (R-TN) & $\$ 2,672,630$ & $13 \%$ & - \\
\hline Robert Menendez (D-NJ) & $\$ 2,540,952$ & $16 \%$ & - \\
\hline Richard C. Shelby (R-AL) & $\$ 2,461,009$ & $28 \%$ & 1 \\
\hline Jack Reed (D-RI) & $\$ 1,732,958$ & $33 \%$ & - \\
\hline Tim Johnson (D-SD) & $\$ 1,520,226$ & $24 \%$ & - \\
\hline Mike Crapo (R-ID) & $\$ 1,419,555$ & $33 \%$ & 7 \\
\hline Kay Bailey Hutchison (R-TX) & $\$ 1,380,399$ & $14 \%$ & - \\
\hline Robert F. Bennett (R-UT) & $\$ 1,161,560$ & $33 \%$ & 8 \\
\hline Sherrod Brown (D-OH) & $\$ 988,007$ & $8 \%$ & - \\
\hline Jim DeMint (R-SC) & $\$ 940,856$ & $14 \%$ & 7 \\
\hline David Vitter (R-LA) & $\$ 859,644$ & $11 \%$ & 7 \\
\hline Jeff Merkley (D-OR) & $\$ 777,387$ & $11 \%$ & - \\
\hline Jon Tester (D-MT) & $\$ 725,487$ & $11 \%$ & 1 \\
\hline Michael Bennet (D-CO) & $\$ 617,676$ & $17 \%$ & 3 \\
\hline Jim Bunning (R-KY) & $\$ 518,440$ & $31 \%$ & - \\
\hline Mike Johanns (R-NE) & $\$ 462,440$ & $11 \%$ & 2 \\
\hline Daniel K. Akaka (D-HI) & $\$ 242,750$ & $8 \%$ & - \\
\hline Judd Gregg (R-NH) & $\$ 218,200$ & $15 \%$ & - \\
\hline Herb Kohl (D-WI) & $\$ 9,400$ & $0 \%$ & - \\
\hline TOTALS & $\$ 41,919,374$ & $22 \%$ & 43 \\
\hline
\end{tabular}

Source: Center for Responsive Politics, http://www.opensecrets.org

*As reported by Sunlight Foundations, http://www.politicalpartytime.org Center for Responsive Politics, http://www.opensecrets.org

The Sunlight Foundations obtains fundraiser invitations but neither receives invitations for all scheduled fundraisers, nor confirms if scheduled fundraisers have taken place. 
TABLE 2.

CONTRIBUTIONS: Financial Sector Contributions to Eight Senators Tasked with Re-Drafting Financial Reform, 2009

\begin{tabular}{|l|rr|rr|r|}
\hline Senator & \multicolumn{2}{|c|}{$\begin{array}{l}\text { Raised from } \\
\text { Financial Industry }\end{array}$} & \multicolumn{1}{l|}{ Total Raised } & \% of Total \\
\hline Mike Crapo (R-ID) & $\$$ & $1,419,555$ & $\$$ & $4,302,690$ & $33 \%$ \\
\hline Charles E. Schumer (D-NY) & $\$$ & $3,086,349$ & $\$$ & $9,895,490$ & $31 \%$ \\
\hline Bob Corker (R-TN) & $\$$ & $2,672,630$ & $\$$ & $20,768,188$ & $13 \%$ \\
\hline Mark Warner (D-VA) & $\$$ & $5,561,561$ & $\$$ & $13,985,292$ & $40 \%$ \\
\hline Christopher J. Dodd (D-CT) & $\$$ & $9,000,975$ & $\$$ & $17,479,197$ & $51 \%$ \\
\hline Richard C. Shelby (R-AL) & $\$$ & $2,461,009$ & $\$$ & $8,815,915$ & $28 \%$ \\
\hline Judd Gregg (R-NH) & $\$$ & 218,200 & $\$$ & $1,437,795$ & $15 \%$ \\
\hline Jack Reed (D-RI) & $\$$ & $1,732,958$ & $\$$ & $5,262,977$ & $33 \%$ \\
\hline TOTALS & $\mathbf{\$}$ & $\mathbf{2 6 , 1 5 3 , 2 3 7}$ & $\mathbf{\$ 8 1}, \mathbf{9 4 7}, \mathbf{5 4 4}$ & $\mathbf{3 2 \%}$ \\
\hline
\end{tabular}

Source: Center for Responsive Politics, http://www.opensecrets.org

TABLE 3.

CONTRIBUTIONS: Industry Breakdown of Financial Sector Contributions to Senate Banking Committee, 2005-2009

\begin{tabular}{|l|cr|}
\hline Financial Industries & $\begin{array}{l}\text { Contributions to } \\
\text { Senate Banking } \\
\text { Committee Members }\end{array}$ \\
\hline Securities \& Investment & $\$$ & $13,943,320$ \\
\hline Real Estate & $\$$ & $8,974,423$ \\
\hline Insurance & $\$$ & $5,580,293$ \\
\hline Misc. Finance & $\$$ & $4,300,009$ \\
\hline Commercial Banks & $\$$ & $3,842,799$ \\
\hline Finance / Credit Cos & $\$$ & $3,136,806$ \\
\hline Accountants & $\$$ & $1,823,438$ \\
\hline Savings \& Loans & $\$$ & 192,986 \\
\hline Credit Unions & $\$$ & 125,300 \\
\hline
\end{tabular}

Source: Center for Responsive Politics, http://www.opensecrets.org 
TABLE 4.

CONTRIBUTIONS: Top Five Bank \& Wall Street Contributors to

Congress, 2009

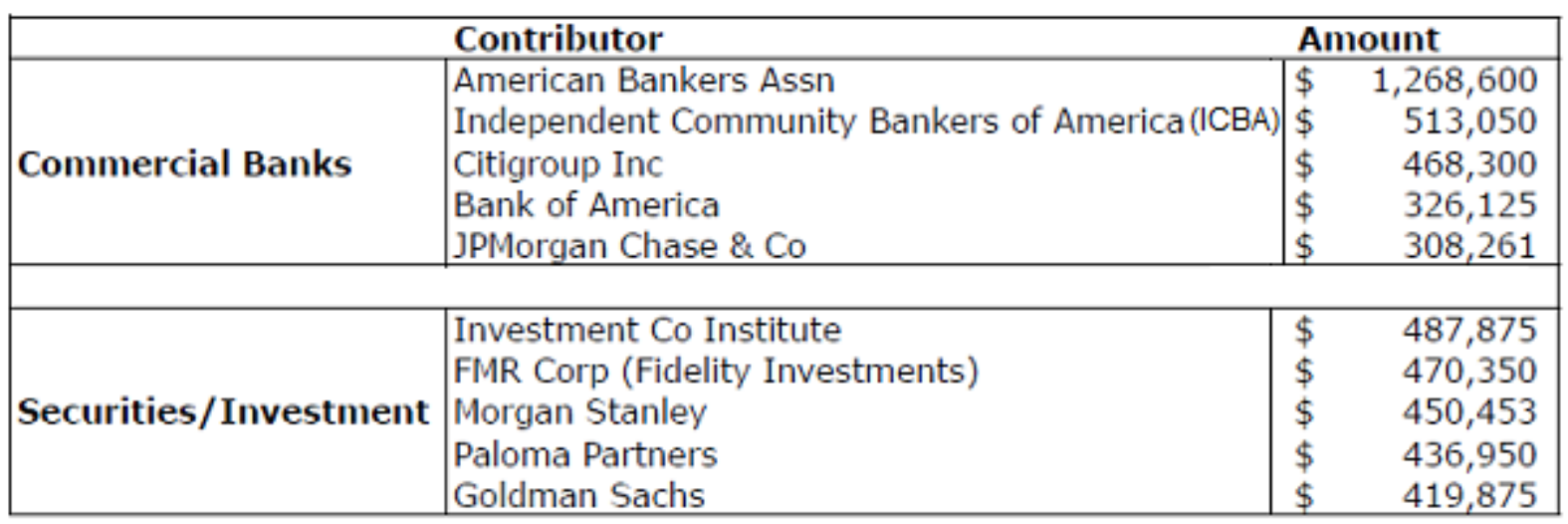

Source: Center for Responsive Politics, http://www.opensecrets.org

Note: ICBA is the trade association representing small banks and savings institutions. This sector's contribution to Congressional coffers in 2009 is exceeded by the combined contributions attributed to the nation's two largest zombie banking firms (Citigroup and Bank of America) and dwarfed by the amount of funding drawn from the securities industry. 
TABLE 5.

LOBBYING: 2009

\begin{tabular}{|l|l|lr|}
\cline { 2 - 4 } \multicolumn{1}{c|}{} & No. of Lobbyists & \multicolumn{2}{|c|}{ Expenditures } \\
\hline Financial Sector & 2567 & $\$$ & $336,005,436$ \\
\hline US Chamber of Commerce & 127 & $\$$ & $52,256,000$ \\
\hline
\end{tabular}

Source: Center for Responsive Politics, http://www.opensecrets.org 